Jurnal Perikanan Pantura (JPP) Volume 1, Nomor 1, Maret 2018

\title{
PENGARUH PENAMBAHAN TEPUNG JAHE EMPRIT(Zingiber officinale var. Amarum) PADA PAKAN TERHADAP PERTUMBUHAN DAN DAYA HIDUP IKAN NILA (Oreochromis niloticus)
}

\author{
Ahmad Hadi Ripaki' ${ }^{1}$ Farikhah $^{2}$, dan Andi Rahmad Rahim ${ }^{2}$ \\ ${ }^{1}$ Mahasiswa Prodi Budi Daya Perikanan Fakultas Pertanian Universitas Muhammadiyah Gresik \\ ${ }^{2}$ Dosen Prodi Budi Daya Perikanan Fakultas Pertanian Universitas Muhammadyah Gresik \\ Email: ahmadhadi635@ gmail.com, Phone: +6282143198165
}

\begin{abstract}
Tilapia (Oreochromis niloticus) is a type of fish that has high economic value. Cultivation is determined by two factors: fish disease and growth. Among the results of immunostimulant studies added in the diet can increase the nonspecific immune response as well as increase the growth of fish, immunostimulant ingredients are one of ginger emprit (Zingiber officinale var Amarum). This study aims to analyze the effect of the addition of ginger flour emprit to growth rate, survival rate and feed conversion ratio of tilapia fish. The research method used was Completely Randomized Design (CRD) consisting of 4 with 3 replications, namely: treatment $\mathrm{A}=5, \mathrm{~B}=7.5, \mathrm{C}=10 \mathrm{~g} / \mathrm{kg}$ of feed and control (no addition of ginger). The main parameters observed were specific growth rate, absolute weight, survival rate and feed conversion ratio. The supporting parameters are water quality consisting of temperature, $\mathrm{pH}$ and DO. Analysis of the data using ANOVA if influenced by further Tukey test $(\mathrm{p}<0,05)$. The results showed that the best growth in this study was in treatment with a dose of $7.5 \mathrm{~g} / \mathrm{kg}$ of feed with an absolute weight of $5.40 \pm 0.34 \mathrm{~g}$, a specific growth rate of $2.41 \pm 0.08 \%$ /day, survival rate that is equal to $90 \pm 0,0 \%$, and feed conversion ratio of $3.6 \pm 0.15 \mathrm{~g}$.
\end{abstract}

Keywords: Tilapia, ginger emprit, Growth, Survival rate, Feed conversion ratio.

\section{PENDAHULUAN \\ Latar Belakang}

Ikannila (Oreochromis niloticus) merupakan jenis ikan yang mempunyai nilai ekonomis tinggi dan permintaan ikan nila terus meningkat dari tahun ke tahun. Data FAO (2009) produksi ikan nila mengalami peningkatan sekitar 769.936 ton pada tahun 2007 menjadi berkisar 2,3 juta ton tahun 2008, pada tahun 2010 diperkirakan mencapai sekitar 2,5 juta ton (FAO, 2010).Ikan nila merupakan komoditas perairan darat yang banyak digemari oleh masyarakat, baik lokal maupun mancanegara (Iskandar, et al., 2011).

Ikan nila juga merupakan spesies ikan yang banyak dibudidayakan untuk memenuhi kebutuhan protein hewani. Konsumsiikan nilamengalami peningkatan yang signifikan dari tahun ke tahun. Namun, potensi yang besar dan prospekpengembangan yang begitu terbuka, bukan jaminan bahwa budidaya ikan akan berjalan mulus, tanpa permasalahan. Pada budidaya ikan pertumbuhan merupakan salah satu tujuan akuakultur yaitu dalam hal pencapaian profit. Diasumsikan bahwa dengan pertumbuhan yang relatif cepat maka pada siklus uang akan semakin cepat dan profit yang didapat akan sebanding pula (Bachtiar, 2006).

Produksi usaha budidaya sangat ditentukan oleh dua faktor yaitu penyakit ikan dan pertumbuhan. Upaya meningkatkan pertumbuhan ikan nila dapat memberikan banyak manfaat seperti memperpendek waktu produksi, meningkatkan efisiensi pakan, dan meningkatkan produksi. Salah satu cara untuk meningkatkan pertumbuhan ikan nila yaitu dengan mengoptimalkan fungsi fisiologis organ tubuh ikan nila yaitu saluran pencernaan. Organ penting 
yang berperan dalam saluran pencernaan adalah usus karena sangat berkaitan dengan aktivitas enzim pencernaan di dalam tubuh ikan (Rojtinnakorn et al. 2012).

Menurut Handayani(2006), enzim-enzim pencernaan memiliki peranan penting dalam proses pencernaan nutrien pakan. Ketersediaan enzim pencernaan akan memengaruhi efektivitas enzim dalam mencerna pakan yangdiberikan,danselanjutnyaberpengaruhpada pertumbuhan. Salah satu cara untuk menstimulasi enzim pencernaan dapatlebih optimal yaitu melalui pemberian bahan alami (feed additive) jaheemprit(Zingiber officinale var. Amarum). Bahan alami merupakan bahan yang ditambahkan dalam jumlah kecil pada formulasi pakan atau pada pakan yang sudah jadi. Bahan ini memilikifungsi untuk mempertahankan karakteristik gizi pakan, sebagai bahan pengawet, perekat atau binder, dan dapat meningkatkan nafsu makan (FAO, 2006).Bahan-bahan imunostimulan tersebut dapat berasal dari berbagai sumber bahan alami yang mudah diperoleh dengan harga yang murah. Untuk maksudtersebut maka akan dilakukan penelitian dengan menggunakan jahe sebagaisumber imunostimulan dengan tujuan untuk meningkatkan pertumbuhan dan daya hidup ikan nila.

\section{STUDI LITERATUR}

\section{Ikan nila (Oreochromis niloticus)}

Berdasarkan morfologinya, ikan nila umumnya memiliki bentuk tubuh panjang dan ramping, dengan sisik berukuran besar. Matanya besar, menonjol, dan bagian tepinya berwarna putih. Gurat sisi (linea literalis) terputus dibagian tengah badan kemudian berlanjut, tetapi letaknya lebih ke bawah dari pada letak garis yang memanjang di atas sirip dada. Sirip punggung, sirip perut, dan sirip dubur mempunyai jari-jari keras dan tajam seperti duri. Sirip punggungnya berwarna hitam dan sirip dadanya juga tampak hitam. Bagian pinggir sirip punggung berwarna abu-abu atau hitam. Ikan nila memiliki lima sirip, yaitu sirip punggung (dorsal fin), sirip dada (pectoral fin), sirip perut (venteral fin), sirip anus (anal fin), dan sirip ekor (caudal fin). Sirip punggung memanjang, dari bagian atas tutup insang hingga bagian atas sirip ekor. Ada sepasang sirip dada dan sirip perut yang berukuran kecil. Sirip anus hanya satu buah dan berbentuk agak panjang. Sementara itu, sirip ekornya berbentuk bulat dan hanya berjumlah satu buah (Amri \& Khairuman, 2002).

Ikan nila memiliki sirip punggung dengan rumus D XV, 10, sirip ekor C II, 15, dan sirip perut $\mathrm{C}$ I, 6. rumus tersebut menunjukkan perincian sebagai berikut: $\mathrm{D} X \mathrm{XV}, 10$ artinya $\mathrm{D}=$ Dorsalis (sirip punggung), $\mathrm{XV}=15$ duri, dan $10=10$ jari-jari lemah. $\mathrm{C}$ II, 15 artinya $\mathrm{C}=\mathrm{Caudalis}$ (sirip ekor) terdiri dari 2 duri, dan 15 jari-jari lemah. V I, 6 artinya V = Ventralis (sirip perut) terdiri dari 1 duri, dan 6 jari-jari lemah (Rukmana,1997). Berdasarkan alat kelaminnya, ikan nila jantan memiliki ukuran sisik yang lebih besar daripada ikan nila betina. Alat kelamin ikan nila jantan berupa tonjolan agak runcing yang berfungsi sebagai muara urin dan saluran sperma yang terletak di depan anus. Jika diurut, perut ikan nila jantan akan mengeluarkan cairan bening (cairan sperma) terutama pada saat musim pemijahan. Sementara itu, ikan nila betina mempunyai lubang genital terpisah dengan lubang saluran urin yang terletak di depan anus. Bentuk hidung dan rahang belakang ikan nila jantan melebar dan berwarna biru muda. Pada ikan betina, bentuk hidung dan rahang belakang agak lancip dan berwarna kuning terang. Sirip punggung dan sirip ekor ikan nila jantan berupa garis putus-putus. Sementara itu, pada ikan nila betina, garisnya berlanjut (tidak putus) dan melingkar (Amri dan Khairuman,2002) 
Jurnal Perikanan Pantura (JPP) Volume 1, Nomor 1, Maret 2018

\section{Jahe emprit (Zingiber officinale var Amarum)}

Jahe putih kecil atau lebih dikenal dengan jahe emprit memiliki rimpang dengan bobot berkisar 0,5-0,7 kg per rumpun. Struktur rimpang jahe emprit, kecil-kecil dan berlapis. Daging rimpang berwarna putih kekuningan. Tinggi rimpangnya dapat mencapai $11 \mathrm{~cm}$ dengan panjang antara 6-30 cm, dan diameter antara 3,27-4,05cm. Kandungan dalam rimpang jahe emprit antara lain minyak atsiri 1,5-3,5\%, kadar pati 54,70\%, kadar serat 6,59\%, dan kadar abu 7,3-8,90\%. Komposisi kimia jahe Menurut Ariviani (1999), jahe memiliki berbagai kandungan zat yang diperlukan oleh tubuh diantara kandungan zat pada jahe adalah minyak atsiri $(0,5-5,6 \%)$, zingiberon, zingiberin, zingibetol, barneol, kamfer, folandren, sineol, gingerin, vitamin (A, B1, dan C), karbohidrat (20-60\%) damar (resin) dan asam - asam organik (malat, oksalat). Jahe seperti halnya jenis rempah-rempah yang lain juga memiliki kemampuan mempertahankan kualitas pangan yaitu sebagai antimikrobia dan antioksidan. Gingerone dan gingerol berperan dalam menghambat pertumbuhan bakteri E. Coli dan B. Subtilis, sedangkan kemampuan antioksidannya berasal dari kandungan gingerol dan shogaol (Uhl, 2000).

\section{METODE PENELITIAN}

Penelitian dilaksanakan pada tanggal 10 Juni sampai 22 Juli 2017 di Laboratorium Perikanan Fakultas Pertanian Universitas Muhammadiyah Gresik.

Bahan uji sebagai perlakuan adalah jahe emprit yang dibeli dari pasar. Jahe tersebut dijadikan tepung kemudian dicampurkan ke dalam pakan pelet komersil (comfeed). Metode yang digunakan dalam penelitian ini adalah metode experiment dengan analisis Rancang Acak Lengkap (RAL) dengan 4 perlakuan 3 kali ulangan yaitu $A=5, B=7,5, C=10 \mathrm{~g} / \mathrm{kg}$ pakan dan kontrol (tanpa jahe emprit).

\section{Prosedur Penelitian \\ Persiapan kolam}

Wadah pemeliharaan yang digunakan adalah ember plastik bundar dengan diameter 35 $\mathrm{cm}$ dan tinggi $40 \mathrm{~cm}$ dengan volume 10 liter. Sebelum digunakan, bak dibersihkan terlebih dahulu selanjutnya, bak di isi dengan air PDAM dan diberi aerator untuk mensuplai oksigen terlarut.

\section{Persiapan ikan uji}

Ikan uji yang digunakan dalam penelitian ini adalah ikan nila (Oreochromis niloticus) ukuran $5 \mathrm{~cm}$, dengan berat rata-rata awal 5 gram/ekor, sebanyak 120 ekor yang didapat dari desa deket kecamatan lamongan yang didapat dari desa deket kecamatan lamongan. Ikan nila ditempatkan dalam kolam untuk diaklimatisasi dan dipuasakan selama 1 hari sebelum dipindahkan ke kolam pemeliharaan. Aklimatisasi merupakan perubahan fisiologis ikan yang membantu mempertahankan fungsi dan organisme dalam kondisi lingkungan yang berbeda. Ikan dipuasakan dengan tujuan agar ikantidak mudah stress karena faktor air dan lingkungan yang berbeda serta dapat memakan pakan yang berupa pellet saat penelitian.

\section{Persiapan pakan}

Penelitian ini menggunakan pakan pellet apung ikan nila dengan kandungan protein $30 \%$. Selanjutnya dikerjakan mengikuti metode yang dikemukakan oleh Nya and Austin (2009). Caranya, pertama jahe yang diperoleh dari pasar dicuci kemudian dipotong menjadi bagianbagian yang lebih kecil, dikeringkan selama 24 jam dalam temperatur ruang. Jahe yang sudah kering selanjutnya dijadikan tepung dengan menggunakan blender dan disaring dengan saringan halus. Jahe yang sudah dalam bentuk tepung selanjutnya ditimbang sesuai perlakuan $(5 \mathrm{~g}, 7,5 \mathrm{~g}$ 
dan $10 \mathrm{~g}$ ). Jahe yang sudah ditimbang dilarutkan dalam sedikit air (100 $\mathrm{mL}$ air untuk pembuatan $1 \mathrm{~kg}$ pakan) kemudian dicampurkan secara merata ke dalam pakan pelet dengan dosis $5 \mathrm{~g}, 7,5 \mathrm{~g}$ dan $10 \mathrm{~g}$ jahe $/ \mathrm{kg}$ pelet dengan cara disemprotkan dengan menggunakan sprayer. Pakan yang sudah ditambahkan jahe selanjutnya di keringkan pada suhu ruang, setelah kering pelet tersebut di simpan pada toples plastik.

\section{Pemberian pakan}

Ikan diberi pakan yang sudah ditambahkan jahe emprit dengan dosis pemberian pakan $5 \%$ dari bobot biomassa awal ikan nila dan diberikan 2 kali sehari yaitu, pukul 08.00 dan pukul 16.00 WIB. Pengamatan pertumbuhan ikan pertambahan bobot ikan. Selama penelitian, kualitas air dikontrol agar tetap berada dalam keadaan baik.

\section{Parameter Penelitian}

Lajupertumbuhan spesifik/spesific (SGR)

Laju pertumbuhan spesifik dihitung dengan menggunakan rumus dari Zonneveld et al.,(1991) :

$$
\mathrm{SGR}=\underline{\ln \mathrm{Wt}-\ln \mathrm{W} 0} \times 100 \%
$$

Keterangan :

SGR : Laju pertumbuhan spesifik (\%/hari)

Wt : Berat rata-rata tubuh ikan pada hari ke-n $(\mathrm{g})$

W0 : Berat rata-rata tubuh ikan pada awal pemeliharaan $(\mathrm{g})$

t : Waktu (hari)

\section{Pertumbuhan bobot mutlak}

Rumus yang digunakan untuk menghitung pertumbuhan bobot mutlak menurut Effendie (2002) adalah :

$$
W=W t-W o
$$

Keterangan :W : Pertumbuhan bobot mutlak (g)Wt : Bobot ikan akhir (g)Wo : Bobot ikan awal (g)

\section{Daya hidup (SR)}

Daya hidup ikan dihitung dengan mengurangi jumlah ikan awal dengan jumlah ikan akhir. Tingkat daya hidup menggunakan rumus (Effendi,2002).

Keterangan:

$$
\boldsymbol{S} \boldsymbol{R}=\frac{\mathrm{Nt}}{\mathrm{No}} \times 100 \%
$$

SR : Survival Rate (\%)

$\mathrm{Nt}$ : Jumlah ikan yang hidup pada akhir pemeliharaan

No : Jumlah ikan pada awal pemeliharaan 
Jurnal Perikanan Pantura (JPP) Volume 1, Nomor 1, Maret 2018

HASIL DAN PEMBAHASAN

Pertumbuhan Ikan Nila (Oreochromis niloticus)

Laju pertumbuhan spesifik (SGR)

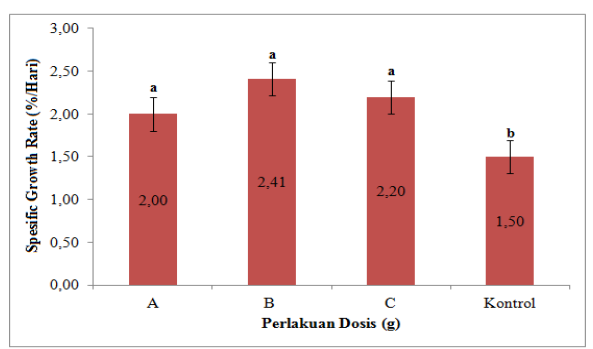

Gambar 1. Hasil pengamatan rerata laju pertumbuhan spesifik ikan nila (Oreochromisniloticus) dengan penambahan jahe emprit dosis $5,7,5,10 \mathrm{~g} / \mathrm{kg}$ dalam pakan selama 42 hari.

Gambar 1 menunjukkan bahwa kisaran laju pertumbuhan spesifik (SGR) selama penelitian ini adalah $1.50 \pm 0.27-2,41 \pm 0,08 \%$ /hari, dengan pertumbuhan tertinggi yaitu pada perlakuan B (Pelet + jahe emprit $7,5 \mathrm{~g} / \mathrm{kg}$ pakan) sebesar $2,41 \pm 0,08 \% /$ hari,dan yang terendah pada perlakuan $\mathrm{K}$ (kontrol) yaitu $1.50 \pm 0.27-2,41 \pm 0,08 \% /$ hari, adapun laju pertumbuhan spesifik masingmasing perlakuan yaitu perlakuan A (Pelet+jahe emprit $5 \mathrm{~g} / \mathrm{kg}$ pakan) sebesar2,00 $\pm 0,22 \% /$ hari,

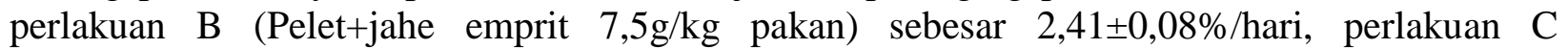
(Pelet+jahe emprit $10 \mathrm{~g} / \mathrm{kg}$ pakan) sebesar 2,20 $\pm 0,14 \% /$ hari dan tanpa penambahan tepung jahe emprit (kontrol) sebesar 1.50 $\pm 0.27 \%$ /hari.

Pertumbuhan bobot mutlak

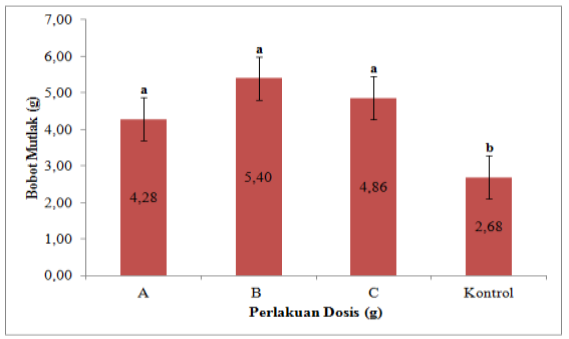

Gambar 2. Hasil pengamatan rerata pertumbuhan bobot mutlak ikan nila (Oreochromis niloticus) dengan penambahan jahe emprit dosis $5,7,5,10 \mathrm{~g} / \mathrm{kg}$ dalam pakan selama 42 hari.

Gambar 2 menunjukkan bahwa kisaran pertumbuhan bobot mutlak selama penelitian ini adalah 2,68 $\pm 0,56-5,40 \pm 0,34 \mathrm{~g}$, dengan pertumbuhan tertinggi yaitu pada perlakuan B (Pelet + jahe emprit $7,5 \mathrm{~g} / \mathrm{kg}$ pakan) sebesar $5,40 \pm 0,34 \mathrm{~g}$,dan yang terendah pada perlakuan $\mathrm{K}$ (kontrol) yaitu $2,68 \pm 0,56 \mathrm{~g}$. Adapun pertumbuhan bobot mutlak masing- masing perlakuan yaitu perlakuan $\mathrm{A}($ Pelet + jahe emprit $5 \mathrm{~g} / \mathrm{kg}$ pakan) sebesar4,28 $\pm 0,66 \mathrm{~g}$, perlakuan B (Pelet + jahe emprit 7,5g/kg pakan) sebesar 5,40 $\pm 0,34 \mathrm{~g}$, perlakuan $\mathrm{C}$ (Pelet + jahe emprit $10 \mathrm{~g} / \mathrm{kg}$ pakan) sebesar 4,86 $\pm 0,35 \mathrm{~g}$

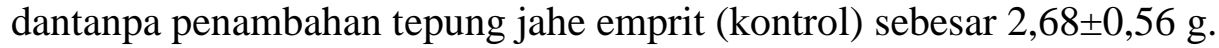

Laju pertumbuhan ikan dipengaruhi oleh jenis dan kualitas pakan yang diberikan diantaranya berkualitas baik, jumlahnya mencukupi, kondisi lingkungan mendukung, dan dapat dipastikan laju pertumbuhan ikan nila akan menjadi cepat sesuai dangan yang diharapkan (Khairuman dan Amri, 2003). Kemampuan mengkonsumsi pakan buatan juga dapat mempengaruhi laju pertumbuhan. Dengan adaptasi terhadap pakan buatan dengan kandungan nutrisi yang tinggi akan mengakibatkan laju pertumbuhannya semakin cepat dan ukuran maksimum bertambah (Effendi, 2004).

Penambahan tepung jahe emprit pada pakan memberikan pengaruh yang nyata terhadap laju pertumbuhan harian dan pertumbuhan bobot mutlak ikan nila dibandingkan 
dengan perlakuan kontrol(tanpa perlakuan). Hal ini diduga akibat adanya zat aktif minyak atsiri dan kurkumin yang terdapat pada jahe emprit.

Kandungan minyak atsiri dalam jahe berfungsi sebagai antibiotik, juga dapat menetralkan racun, meningkatkan sekresi empedu, sehingga dapat meningkatkan nafsu makan pada ikan uji, selain itu minyak atsiri dapat memperbaiki kerja sistem pencernaan dan digunakan sebagai bahan pemacu pertumbuhan dan meningkatkan daya cerna (Setianingrum, 1999). Koesdarto (2001) menyatakan bahwa meningkatnya pertumbuhan didukung dengan kesehatan yang baik pada ikan dan akan meningkatkan efisiensi penyerapan zat makanan untuk memenuhi kebutuhan hidup dan produksi yang ditunjukkan dengan pertambahan bobot. Menurut Punitha et al. (2008), penambahan jahe dalam pakan dapat meningkatkan pertumbuhan sebab jahe selain mengandung bahan-bahan anti mikroba dan imunostimulan, juga mengandung bahan-bahan yang dapat meningkatkan nafsu makan ikan (appetizer).

Zat aktif kurkumin yang terdapat pada jahe emprit yang dapat meningkat-kan jumlah konsumsi pakan. Semakin tinggi pakan yang dikonsumsi dapat meningkatkan jumlah substrat untuk enzim, sehingga aktivitas enzim meningkat (Rojtinnakorn et al. 2012). Menurut Rungruangsak-Torrissen et al. (2009), tingginya aktivitas enzim pencernaan dapat dihubungkan dengantingginya pakan yang dikonsumsi atau tingginya pemanfaatan pakan yang berpengaruh pada pertumbuhan somatik. Penambahan tepung jahe emprit 7,5 g menghasilkan bobot tubuh akhir ikan dan laju pertumbuhan harian tertinggi pada ikan.Hal ini disebabkan oleh zat aktif kurkumin yang terdapat di dalam tepung jahe emprit bekerja secara efektif sehingga penyerapan nutrien lebih tinggi. Menurut Darwis et al. (1991), kurkumin memiliki fungsi yang dapat merangsang dinding kantung empedu untuk mengeluarkan cairan empedu ke dalam usus halus sehingga meningkatkan pencernaan lemak, protein dan karbohidrat sehingga aktivitas penyerapan zat-zat makanan meningkat.

\section{Daya Hidup (SR)}

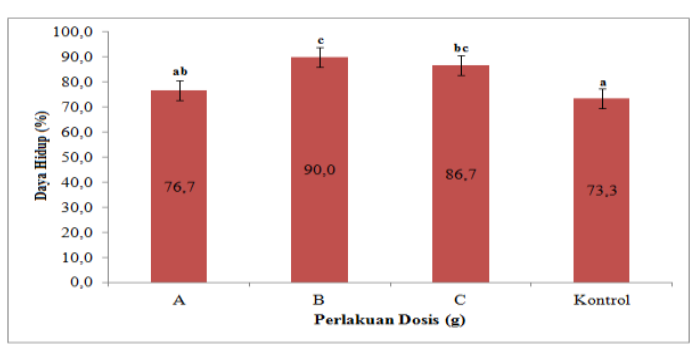

Gambar 3. Hasil pengamatan rerata daya hidup ikan nila (Oreochromis niloticus) dengan penambahan jahe emprit dosis $5,7,5,10 \mathrm{~g} / \mathrm{kg}$ dalam pakan selama 42 hari.

Gambar 3 menunjukkan bahwa kisaran daya hidup ikan nila selama penelitian ini adalah $73,3 \pm 5,77-90 \pm 0.0 \%$, dengan daya hidup tertinggi yaitu pada perlakuan B (Pelet+jahe emprit $7,5 \mathrm{~g} / \mathrm{kg}$ pakan) sebesar $90 \pm 0.0 \%$, dan yang terendah pada perlakuan $\mathrm{K}$ (kontrol) yaitu $73,3 \pm 5,77 \%$. Adapun daya hidup masing- masing perlakuan yaitu perlakuan A (Pelet+jahe emprit $5 \mathrm{~g} / \mathrm{kg}$ pakan) sebesar76,7 $\pm 5.77 \%$, perlakuan B (Pelet+jahe emprit $7,5 \mathrm{~g} / \mathrm{kg}$ pakan) sebesar $90 \pm 0.0 \%$, perlakuan C (Pelet+jahe emprit $10 \mathrm{~g} / \mathrm{kg}$ pakan) sebesar $86,7 \pm 5,77 \%$ dan tanpa penambahan tepung jahe emprit (kontrol) sebesar 73,3 $\pm 5,77 \%$.

Penambahan jahe emprit pada pakan diduga dapat meningkatkan daya hidup ikan nila di bandingkan perlakuan tanpa tambahan jahe (perlakuan kontrol) jahe memiliki potensi untuk meningkatkan respon kebal non-spesifik ikan. Hal ini disebabkan jahe mengandung bahan-bahan yang berfungsi sebagai imunostimulan (Setyaningrum dan Saparinto, 2013). Imunostimulan 
adalah zat kimia, obat-obatan, stressor, atau aksi yang meningkatkan respon imun non-spesifik atau bawaan (innate-immune respon) yang berinteraksi secara langsung dengan sel dari sistem yang mengaktifkan respon imun bawaan tersebut (Syakuri dkk., 2003). Imunostimulan dapat digunakan sebagai terapi tambahan untuk penyakit yang disebabkan oleh infeksi virus, bakteri dan parasit serta membantu meringankan gejala penyakit infeksi, serta mempercepat proses penyembuhan pada ikan (Rantetondok, 2002). Jika belum terkena penyakit, imunostimulan bisa dipakai sebagai tindakan preventif untuk mencegah penyakit, serta untuk meningkatkan daya tahan tubuh.

Imunostimulan bekerja dengan cara meningkatkan aktivitas sel-sel fagosit untuk melakukan pemangsaan terhadap partikel asing atau patogen yang masuk kedalam tubuh (Raa, 2000). Dalam hal ini imunostimulan seperti karbohidrat (lipopolisakarida, betaglukan, peptidoglikan, karagenan) akan berikatan dengan reseptor yang ada pada permukaan sel fagosit sehingga sel fagosit menjadi aktif untuk melakukan proses fagositosis.

\section{Kualitas Air}

Tabel 1. Hasil pengamatan kualitas air ikan nila (Oreochromis niloticus) dengan penambahan jahe emprit dosis 5 , $7,5,10 \mathrm{~g} / \mathrm{kg}$ dalam pakan selama 42 hari

\begin{tabular}{llll}
\hline Perlakuan & Suhu $\left({ }^{\mathbf{0}} \mathbf{C}\right)$ & Ph & DO $(\mathbf{m g} / \mathbf{l})$ \\
\hline A & $27,7-28,7$ & $7,4-7,5$ & $3,93-4,05$ \\
B & $27,6-28,5$ & $7,1-7,6$ & $3,94-4,18$ \\
C & $27,8-28,3$ & $7,1-7,7$ & $3,81-4,46$ \\
Kontrol & $27,8-28,9$ & $7,4-7,7$ & $3,74-3,94$ \\
\hline
\end{tabular}

Tabel 1 menunjukkan bahwa kualitas air berupa suhu, $\mathrm{pH}$ dan DO tidak berpengaruh terhadap perlakuan penelitian karena suhu, $\mathrm{pH}$ dan $\mathrm{DO}$ sesuai dengan kebutuhan ikan nila. Berdasarkan hasil pengukuran kualitas air suhu, $\mathrm{pH}$ dan $\mathrm{DO}$ yaitu suhu $27,6^{\circ} \mathrm{C}-28,9^{\circ} \mathrm{C}$, nilai $\mathrm{pH}$ 7,1-7,7 danDO 3,74-4,46 mg/l. Ikan nila mempunyai kemampuan tumbuh secara normal pada kisaran suhu $14-38^{\circ} \mathrm{C}$ dengan suhu optimum bagi pertumbuhan dan perkembangannya yaitu $25-$ $30^{\circ} \mathrm{C}$ (Amri, 2003).

\section{KESIMPULAN DAN SARAN \\ Kesimpulan}

Kesimpulan dari hasil penelitian ini antara lain sebagai berikut:

1. Pertumbuhan terbaik pada penelitian ini ada pada perlakuan dengan dosis $7,5 \mathrm{~g} / \mathrm{kg}$ pakan

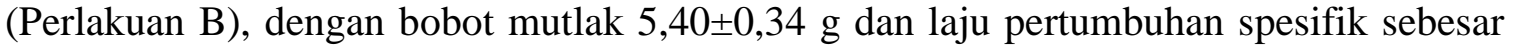
$2,41 \pm 0,08 \% /$ hari

2. Daya hidup terbaik pada penelitian ini ada pada perlakuan dengan dosis $7,5 \mathrm{~g} / \mathrm{kg}$ pakan (Perlakuan B) yaitu sebesar 90 $\pm 0,0 \%$

\section{Saran}

Pada penelitian ini pembesaran benih ikan nila (Oreochromis niloticus) dengan penambahan tepung jahe emprit $7,5 \mathrm{~g} / \mathrm{kg}$ pakan dapat meningkatkan laju pertumbuhan, daya hidup dan dapat menurunkan nilai rasio konversi pakan. Hasil penelitian ini dapat direkomendasikan untuk melakukan penelitian lanjutan dengan melakukan penelitian uji sel darah.

\section{UCAPAN TERIMA KASIH}

Dalam kesempatan ini pula penulis mengucapkan terima kasih kepada yang terhormat: 
1. Ibu Ir. Endah Sri Redjeki, M.P., M. Phill selaku Dekan Fakultas Pertanian Universitas Muhammdiyah Gresik.

2. Bapak Dr. Andi Rahmad Rahim, S.Pi., M.Si selaku Ketua Program Studi Budi Daya Perikanan Universitas Muhammadiyah Gresik.

3. Ibu Farikhah, S.Pi., M.Siselaku Dosen Pembimbing Skripsi I Program Studi Budidaya Perikanan UniversitasMuhammadiyah Gresik.

4. Bapak Dr. Andi Rahmad Rahim, S.Pi., M.Si selakuDosen Pembimbing Skripsi II Program Studi Budidaya Perikanan Universitas Muhammadiyah Gresik.

5. Semua pihak yang telah membantu dalam penyusunan laporan ini.

Penulis menyadari laporan ini masih jauh dari sempurna, oleh karena itu penulis mengharapkan kritik dan saran yang bersifat membangun dari semua pihak, demi perbaikan laporan di masa yang akan datang.

\section{DAFTAR PUSTAKA}

Amri, K, Khairuman. 2002. Buku Pintar Budidaya 15 Ikan Konsumsi. Agromedia. Jakarta. Amri,K,Khairuman. 2003. Budidaya Ikan Nila Secara Intensif.Jakarta: Agromedia Pustaka.

Ariviani,S.1999. Daya Tangkal Radikal dan Aktivitas Penghambatan Pembentukan Peroksida Sistem Linoleat Ekstrak Rimpang Jahe, Laos, Temulawak, dan Temuireng. Skripsi Fakultas Teknologi Pertanian UGM.Yogyakarta.

Bachtiar, Y. 2006. Panduan Lengkap Budidaya Ikan Nila. Agromedia. Jakarta.

Boyd. 2004. SNI 01-6139-1999 (Produksi induk ikan nila hitam, Oreochromis niloticus). Jakarta 4 hal.

Effendi. 2004. Biologi Ikan Nila. Yayasan Pustaka Nusatama. Jakarta. 54 hal

Food \& Agruculture Organization of the United Station (FAO). 2010. FAO Yearbook. Fishery and Aquaculture Statistic.http://www.fao.org/fishery/Culturedspecies/Orechromisniloticus/en （ 15mei 2017).

Handayani,S. 2006.Studi efisiensi pemanfaatan karbohidrat pakan bagi pertumbuhan ikan gurame (Osphronemus gouramy Lac.) se-jalan dengan perubahan enzim pencernaan dan insulin. TesisProgram Pascasarjana Institut Pertanian Bogor. 107 hlm.

Iskandar, A. 2011. Budidaya Ikan Nila (Oreochromis, niloticus). Karya Putra Darawati. Bandung. $69 \mathrm{hlm}$

Kordi, G. 2000. Budidaya Ikan Nila. Dahara Prize. Jakarta.

Koswara, S. 1995. Jahe dan Hasil Olahannya. Pustaka Sinar Harapan. Jakarta.

Nya EJ, Austin B. 2009. Use of dietary ginger, Zingiber officinale Roscoe, as an Imunostimulant to control Aeromonas hydrophilainfections in rainbow trout, Oncorynchus mykiss (Walbaum). Jounal of Fish Diseases 32: 971-977

Mulia, D.S. 2006. Tingkat Infeksi Ektoparasit Proozoa Pada Benih Ikan Nila (Oreochromis niloticus) di Balai Benih Ikan (BBI) Pandak dan Sidabowa, Kabupaten Banyumas. Skripsi. Fakultas Perikanan dan Ilmu Kelautan Universitas Muhammadiyah Purwokerto, Purwokerto.

Nya EJ, Austin B. 2009. Use of dietary ginger, Zingiber officinale Roscoe, as an Imunostimulant to control Aeromonas hydrophilainfections in rainbow trout, Oncorynchus mykiss (Walbaum). Jounal of Fish Diseases 32: 971-977 


\section{$\underline{\text { Jurnal Perikanan Pantura (JPP) Volume 1, Nomor 1, Maret } 2018}$}

Pais,R. Khushiramani, R, Karunasagar, I, Karunasagar I. 2008. Effec of immunostimulants on hemolymph haemagglutinins of tiger shrimp Penaeus monodon. Aquac Res 38: 13391345

Pascual, S. 2009. Nutrition and feeding of fish. Van nostrand Reinhold, p.11-91, New York.

Punitha, S.M.J. Babu, M.M. Sivaram, V. Shankar, V.S. Dhas, S.A. Mahesh, T.C, Immanuel, G. Citarasu, T. 2008. Immunostimulating influence of herbal biomedicines on nonspecific immunity in Grouper Epinepheleus tauvina juvenile against Vibrio harveyi infection. Aquacult int 16:511-523

Rantetondok,A. 2002. Pengaruh imunostimulan-Glucan dan Lipopolisakarida terhadap respon imun dan sintasan udang windu. (Penaeus monodon Fab) Disertasi. Program Pascasarjana. Universitas Hasanuddin. Makassar.

Rojtinnakorn, J. Rittiplang, S. Tongsiri, S. Chaibu, P. 2012. Tumeric extract inducing growth biomarker in sand goby (Oxyeleotris mar-moratus). 2nd International Conference on Chemical, Biological and Environment Sciences,41-42.

Setyaningrum, H.D, Saparinto C. 2013. Jahe. Cetakan 1. Penebar Swadaya, Jakarta

Syakuri, H. Triyanto, dan K.H. Niitimulyo. 2003. Perbedaan Daya Tahan Non Spesifik Lima Spesies Ikan Air Tawar Terhadap Infeksi Aeromonas hydrophila. Jurnal Perikanan Universitas Gadjah Mada Vol V (2): hal 1- 10.

Uhl, S.R. 2000. Handbook of Spices, Seasonings and Flavoring. TechnomicPublishing Co. Inc. Lancaster-USA. 